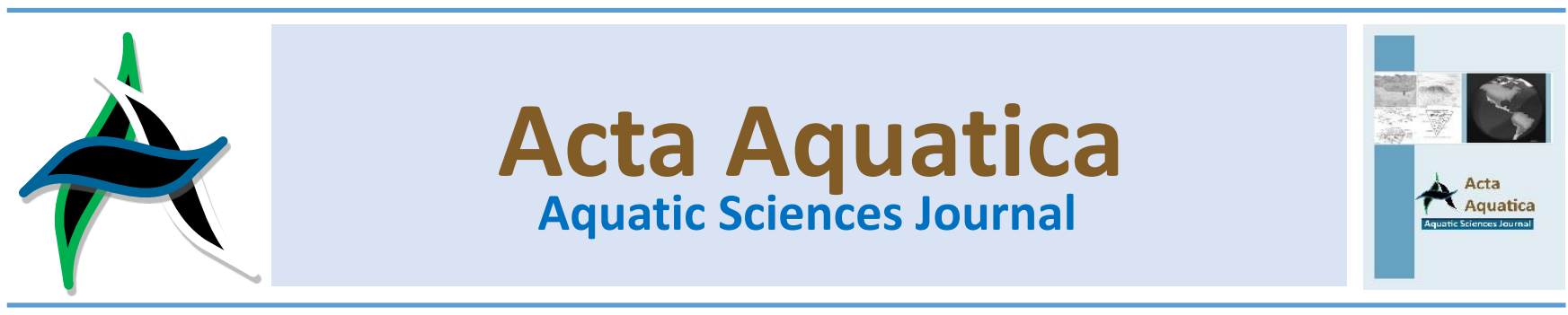

\title{
Pengaruh penggunaan probiotik pada media pemeliharaan terhadap benih maskoki (Carassius auratus) pada umur yang berbeda
}

\author{
Influence of probiotics in fish culture media to goldfish larvae (Carassius auratus) at different \\ ages
}

\author{
Vivi Juliyanti ${ }^{*}$, Salamah $^{\text {a }}$ dan Muliani $^{\text {a }}$ \\ a Program Studi Budidaya Perairan, Fakultas Pertanian, Universitas Malikussaleh
}

\begin{abstract}
Abstrak
Penelitian ini dilakukan di Laboratorium Hatchery dan Teknologi Budidaya Perairan Program Studi Budidaya perairan Fakultas Pertanian Universitas Malikussaleh, dimulai dari tanggal 27 April - 26 Mei 2015. Tujuan penelitian ini adalah mengetahui dosis probiotik yang tepat pada pemeliharaan untuk dapat menjaga kualitas air dan mengetahui umur benih yang tepat untuk dapat memanfaatkan probiotik dengan baik sehingga meningkatkan pertumbuhan dan kelangsungan hidup benih maskoki. Metode yang digunakan dalam penelitian ini dilakukan secara eksperimental dengan menggunakan Rancangan Acak Lengkap (RAL) pola faktorial dengan dua faktor. Perlakuan yang digunakan yaitu enam perlakuan dan tiga ulangan dengan pemberian probiotik 1,5 mg/L-2,0 mg/L untuk benih maskoki berumur satu dan dua bulan. Hasil penelitian menunjukkan bahwa penggunaan probiotik pada media pemeliharaan berpengaruh sangat nyata terhadap pertumbuhan berat dan kualitas air tetapi tidak berpengaruh terhadap pertumbuhan panjang, kelangsungan hidup, dan konversi pakan benih maskoki (Carassius auratus) pada umur yang berbeda. Hasil pengamatan menunjukkan bawah parameter kualitas air yang diukur selama penelitian menunjukkan kisaran yang sesuai atau masih dapat ditolerir untuk pemeliharaan benih ikan maskoki yaitu dengan kisaran suhu $27,1-27,7{ }^{\circ} \mathrm{C}, \mathrm{DO} 6,0-9,0 \mathrm{mg} / \mathrm{L}, \mathrm{pH} 7,2-7,5$, amonia 0,03-0,12 $\mathrm{mg} / \mathrm{L}$, nitrit 0,012-0,090 $\mathrm{mg} / \mathrm{L}$, dan nitrat 0,023-3,52 mg/L. Perlakuan A2B2 dengan dosis $1,5 \mathrm{ml} / \mathrm{L}$ pada benih berumur dua bulan merupakan dosis terbaik yang menghasilkan kelangsungan hidup tertinggi sebesar 73,33\%, namun laju pertumbuhan panjang, berat, dan nilai konversi tertinggi terdapat pada perlakuan A3B2 dengan dosis $2,0 \mathrm{ml} / \mathrm{L}$ pada benih berumur dua bulan yaitu sebesar $0,39 \mathrm{~cm}, 0,52 \mathrm{gr}$, dan $0,48 \mathrm{gr}$.
\end{abstract}

\begin{abstract}
The research was conducted at the Laboratory of Agriculture Hatchery and Technology Aquaculture Departement Faculty of Agriculture, Malikussaleh University, started on April $27^{\text {th }}$ to Mey $26^{\text {th }}$ 2015. The purpose of this study is know the dosage probiotics proper in maintenance for can keep of water quality and know age larvae proper to can use probiotics well raising growth and survival seed goldfish. The research used experimental method with factorials by using complete randommized design (CRD) with two factors. Those who used the six treatment and three remedial by the provision of probiotics $1.5 \mathrm{mg} / \mathrm{I}-2,0 \mathrm{mg} / \mathrm{I}$ for seed maskoki mature in one and two months. The research results show that the use of probiotics in a media maintenance influential very real on the growth of heavy and water quality but has not been affecting the growth long, survival, and conversion of the feed goldfish larvae at the age of different .Our observations showed under parameter a quality of water that measured for research shows a range appropriate or can still be tolerated for the maintenance of goldfish larvae namely by the temperature range $27,1-27,7^{\circ} \mathrm{C}, \mathrm{DO} 6,0-9,0 \mathrm{mg} / \mathrm{L}$, $\mathrm{pH} 7,2-7,5$, ammonia 0,03-0,12 mg/L, nitrites 0,012-0,090 mg/L, and nitrate $0,023-3,52 \mathrm{mg} / \mathrm{L}$. Treatment with doses A2B2 1.5 $\mathrm{mg} / \mathrm{L}$ on larvae was two months is doses best that produces survival highest of $73,33 \%$, but growth rate long, heavy, and the conversion is highest in treatment A3B2 with doses $2,0 \mathrm{ml} /$ I on larvae was two months is as much as $0.39 \mathrm{~cm}, 0,52 \mathrm{gr}$, and 0,48 gr.
\end{abstract}

Keywords: Probiotic; Growth; Ornamental fish

\footnotetext{
* Korespondensi: Prodi Budidaya Perairan, Fakultas Pertanian,

Universitas Malikussaleh. Kampus utama Reuleut,

Kabupaten Aceh Utara, Aceh, Indonesia.

Tel: +62-645-41373 Fax: +62-645-59089.

e-mail: vivijuliyanti02@gmail.com
} 


\section{Pendahuluan}

Indonesia memiliki perairan tawar yang sangat luas dan berpotensi besar untuk usaha berbagai macan jenis ikan air tawar. Ikan hias air tawar merupakan salah satu alternatif usaha untuk menjalankan perekonomian yang banyak menghasilkan devisa. Salah satu ikan hias yang cukup terkenal di kalangan penggemar ikan adalah maskoki (Effendi, 1993). Ikan Maskoki (Carassius auratus) adalah jenis ikan hias yang memiliki nama lain gold fish dengan bentuk tubuh beragam dan memiliki warna bervariasi mulai dari merah, kuning, hijau, hitam sampai keperakperakan (Afrianto dan Liviawaty, 1990). Ikan maskoki sudah digunakan sebagai ikan hias sejak abad ke-7. Ikan maskoki juga memiliki harga yang stabil di pasaran dengan permintaan pasar yang terus meningkat. Ikan maskoki memiliki keistimewaan yang dapat dilihat dari keanekaragaman warna, jenis dan keindahan sirip-siripnya.

Banyak faktor yang dapat mempengaruhi kegiatan budidaya, seperti umur, padat tebar dan kualitas air media pemeliharaan ikan. Salah satu upaya yang dapat dilakukan untuk menjaga kualitas air tetap baik adalah penggunaan probiotik pada media pemeliharaan ikan. Probiotik merupakan mikroba (jasad renik) yang bersifat menguntungkan, bisa berupa fungi (jamur), actinomycetes, bakteri, maupun mikroalga (Suprapto dan Samtamsir, 2013). Pemberian probiotik pada media pemeliharaan diharapkan dapat memperbaiki kualitas air, meningkatkan kelangsungan hidup dan pertumbuhan benih sehingga ketersediaan benih ikan maskoki dapat meningkat. Penggunaan probiotik saat ini merupakan alternatif dalam mengatasi permasalahan yang berkaitan dengan pengelolaan kualitas air.

Media pemeliharaan ikan maskoki harus tetap bersih dari kotoran dan racun, hal itu dapat dibantu dengan penggunaan probiotik. Probiotik berguna untuk penetralisir air agar ikan terlindung dari racun dan bakteri-bakteri penyebab penyakit. Selain itu kualitas air seperti suhu, $\mathrm{pH}$, amonia, dan Dissolved Oxygen (DO) harus terkontrol, agar kelangsungan hidup dan pertumbuhan benih maskoki dalam media pemeliharaan dapat meningkat. Sejauh ini belum diketahui konsentrasi probiotik pada media pemeliharaan untuk dapat menjaga kualitas air, meningkatkan pertumbuhan dan kelangsungan hidup benih ikan maskoki (Carasius auratus), sehingga perlu dilakukan penelitian untuk mengetahui konsentrasi yang efektif dari penambahan bakteri probiotik sehingga dapat menjaga kualitas air media pemeliharaan agar dapat meningkatkan pertumbuhan dan kelangsungan hidup benih maskoki (Carasius auratus).

\section{Bahan dan Metode}

\subsection{Waktu dan tempat}

Penelitian ini dilaksanakan pada tanggal 27 April - $26 \mathrm{Mei}$ 2015 yang bertempat di Laboratorium Hatchery dan Teknologi Budidaya Program Studi Budidaya Perairan Fakultas Pertanian Universitas Malikussaleh.

\subsection{Bahan dan alat}

Adapun alat dan bahan yang akan digunakan untuk penelitian ini dapat dilihat pada Tabel 1 berikut ini:
Tabel 1

Alat dan bahan yang digunakan dalam penelitian serta fungsinya.

\begin{tabular}{cll}
\hline No & \multicolumn{1}{c}{ Alat/bahan } & \multicolumn{1}{c}{ Fungsinya } \\
\hline 1. & Ember kapasitas 30 I & Wadah pemeliharaan ikan \\
2. & Perangkat aerasi & Penyuplai oksigen \\
3. & Backerglass $50 \mathrm{ml}$ & Mengukur dosis probiotik \\
4. & Timbangan analitik & Mengukur bobot ikan \\
5. & Ph meter & Mengukur ph \\
6. & Do meter & Mengukur do dan suhu \\
7. & Spectrophotometer & Mengukur amonia \\
8. & Penggaris & Mengukur panjang ikan \\
9. & Toples & Menyimpan pakan ikan \\
10. & Serok & Menangkap ikan uji pada tiap perlakuan \\
11. & Kamera & Dokumentasi \\
12. & Air tawar & Medi pemeliharaan ikan \\
13. & Benih ikan maskoki & Objek penelitian \\
14. & Probiotik & Menjaga kualitas air \\
15. & Gula & Sumber karbon \\
16. & Pelet & Pakan ikan \\
17. & Deterjen & Membersihkan wadah \\
\hline
\end{tabular}

\subsection{Metode dan rancangan penelitian}

Metode penelitian dilakukan secara eksperimental dengan menggunakan Rancangan Acak Lengkap (RAL) pola faktorial dengan dua faktor, dimana faktor pertama terdiri atas tiga taraf dan faktor kedua terdiri atas dua taraf. Masing-masing diulang sebanyak 3 kali.

A1b1 : Tanpa pemberian probiotik dengan benih maskoki umur satu bulan (kontrol).

A1b2 : Tanpa pemberian probiotik dengan benih maskoki umur dua bulan (kontrol).

A2b1 : Pemberian probiotik dengan dosis $1,5 \mathrm{ml} / \mathrm{L}$ dengan benih ikan maskoki umur satu bulan.

A2b2 : Pemberian probiotik dengan dosis $1,5 \mathrm{ml} / \mathrm{L}$ dengan benih ikan maskoki umur dua bulan.

A3b1 : Pemberian probiotik dengan dosis $2,0 \mathrm{ml} / \mathrm{L}$ dengan benih ikan maskoki umur satu bulan.

A3b2 : Pemberian probiotik dengan dosis $2,0 \mathrm{ml} / \mathrm{L}$ dengan benih ikan maskoki umur dua bulan.

\subsubsection{Persiapan wadah pemeliharaan}

Wadah yang digunakan dalam penelitian ini adalah ember dengan kapasitas $30 \mathrm{~L}$ air sebanyak 18 unit. Sebelum digunakan ember dibersihkan dengan menggunakan deterjen lalu dibilas dan dibiarkan sampai kering. Kemudian akuarium di isi air tawar sebanyak 20 L pada masing-masing wadah perlakuan dan dilakukan pemasangan aerasi. Air yang telah dimasukkan kedalam wadah tersebut dibiarkan selama 24 jam sambil diaerasikan.

\subsubsection{Persiapan ikan uji}

Benih maskoki diperoleh dari pedagang ikan hias di kawasan Kota Lhokseumawe, benih yang dipilih dalam keadaan sehat, lincah, tidak cacat, dan tidak terserang penyakit. Jenis benih maskoki yang digunakan yaitu maskoki Oranda berumur satu dan dua bulan yang berukuran panjang 1,5-4,6 cm dengan berat 0,5-4,5 gram dengan jumlah 360 ekor. Benih maskoki tersebut akan ditebarkan kedalam masing-masing wadah perlakuan dengan jumlah 20 ekor/wadah.

\subsubsection{Aklimatisasi}

Penebaran benih maskoki dilakukan pada pagi hari, sebelum digunakan benih maskoki diadaptasikan terlebih dahulu. Proses adaptasi dilakukan selama 24 jam sebelum 
dimasukkan kedalam wadah pemeliharaan yang telah ditambahkan probiotik. Tujuan adaptasi disini yaitu agar benih maskoki yang akan digunakan dapat menyesuaikan diri dengan kondisi lingkungan yang baru sehingga benih maskoki tidak mengalami stres.

\subsubsection{Persiapan probiotik}

Probiotik yang digunakan dalam penelitian ini yaitu produk probiotik komersil (EM4). Penambahan probiotik dilakukan setiap satu minggu sekali pada masing-masing wadah penelitian dengan dosis yang telah ditentukan, sedangkan untuk wadah perlakuan kontrol tidak ditambahkan probiotik.

\subsubsection{Sumber karbon}

Sumber karbon yang digunakan dalam penelitian ini yaitu gula pasir. Penggunaan gula pasir didasarkan pada kemudahan dalam mencari sumber karbon tersebut. Pada masing-masing wadah penelitian akan ditambahkan gula pasir yang telah diencerkan dengan $\mathrm{C} / \mathrm{N}$ rasio 8:1 (Suprapto dan Samtamsir, 2013), sedangkan pada perlakuan kontrol tidak ditambahkan gula pasir. Perhitungan dosis sumber karbon menggunakan perhitungan Schryver et. al. (2008).

\subsubsection{Pelaksanaan penelitian}

Probiotik ditambahkan pada masing-masing wadah perlakuan di awal penelitian dan ditambahkan gula pasir. Setelah itu dibiarkan selama 24 jam kemudian baru dilakukan penebaran biota uji. Penambahan probiotik pada masing-masing wadah perlakuan dilakukan seminggu sekali sesuai dengan dosis awal dan pemberian sumber karbon dilakukan setiap hari, sedangkan untuk kontrol tidak ditambahkan probiotik maupun sumber karbon. Adapun penambahan probiotik setiap minggu pada media pemeliharaan ikan sesuai dengan pernyataan Astutik (2010) yang menyatakan bahwa probiotik cukup ditambahkan ke air kolam pada pagi hari setiap satu minggu sekali supaya air selalu sehat, tidak blooming dan penuh dengan plankton sebagai pakan alami.

Penelitian ini dilakukan selama 28 hari dan untuk pakan benih maskoki diberikan pakan berupa pelet dengan kandungan protein kasar $30 \%$, lemak kasar $3 \%$, serat kasar $4 \%$, kadar abu $12 \%$, dan kandungan air $12 \%$. Dosis pemberian pakan yaitu $3 \%$ dari bobot biomassa benih maskoki dengan frekuensi pemberian 2 kali sehari, yaitu pada pukul 09.00 dan 16.00 WIB.

Selama pemeliharaan tidak dilakukan pergantian air dan penyiponan. Jumlah volume air dilakukan pengecekan secara periodik agar air tidak berkurang dengan mengamati ketinggiannya. Penambahan air hanya akan dilakukan apabila air di dalam wadah perlakuan berkurang akibat proses penguapan dan pengambilan sampel air.

\subsection{Pengumpulan data}

\subsubsection{Kualitas air}

Kualitas air yang diukur selama pemeliharaan ikan maskoki meliputi oksigen terlarut (DO), derajat keasaman $(\mathrm{pH})$, dan suhu yang diukur dua kali sehari pada pagi dan sore hari, sedangkan untuk amonia dan nitrit, dan nitrat diukur tujuh hari sekali.

\subsubsection{Pertumbuhan}

Untuk mengetahui pertumbuhan ikan Maskoki, dilakukan sampling panjang dan penimbangan bobot ikan. Pengukuran pertumbuhan benih maskoki baik pengukuran panjang maupun penimbangan bobot dilakukan setiap tujuh hari sekali dengan mensampling 10 ekor/wadah perlakuan. Bobot ikan diukur menggunakan timbangan analitik, sebelum ditimbang ikan dipuasakan terlebih dahulu selama 24 jam. Pertumbuhan bobot dihitung berdasarkan rumus pertumbuhan berat menurut Effendie (1979) dalam Parasmewari et. al. (2013):

$$
W=W t-W_{0}
$$

Keterangan:

$\mathrm{W}=$ Pertumbuhan berat $(\mathrm{g})$

$\mathrm{Wt}=$ Pertumbuhan berat rata-rata pada akhir pendederan (g)

$\mathrm{W}_{0}=$ Pertumbuhan berat rata-rata pada awal penelitian $(\mathrm{g})$

Sedangkan pengukuran panjang ikan diukur menggunakan penggaris. Hasil sampling panjang total ikan maskoki digunakan untuk mengukur pertumbuhan panjang yang dihitung menggunakan rumus Effendie (1979) dalam Parasmewari et. al. (2013):

$$
L=L t-L_{0}
$$

Keterangan:

$\mathrm{L} \quad=$ Pertumbuhan panjang $(\mathrm{cm})$

Lt $\quad$ = Panjang akhir $(\mathrm{cm})$

$\mathrm{L}_{0} \quad$ = Panjang awal $(\mathrm{cm})$

\subsubsection{Kelangsungan hidup (SR)}

Tingkat kelangsungan hidup ikan selama pemeliharaan dihitung menggunakan rumus Effendie (1979) dalam Parasmewari et. al., (2013) :

$$
\mathrm{SR}=\frac{\mathrm{Nt}}{\mathrm{N}_{0}} \times 100 \%
$$

Keterangan:

$\mathrm{SR} \quad=$ Kelangsungan hidup (\%)

$\mathrm{Nt}=$ Jumlah ikan pada akhir pemeliharaan

No = Jumlah ikan pada awal penebaran

\subsubsection{Konversi pakan}

Murtidjo (2001) menyatakan bahwa konversi pakan dapat dihitung dengan menggunakan rumus sebagai berikut:

$$
\mathrm{FCR}=\frac{\mathrm{F}}{\left(\mathrm{Wt}-\mathrm{W}_{0}\right)}
$$

Keterangan:

$\begin{array}{ll}\mathrm{FCR} & =\text { Konversi pakan } \\ \mathrm{Wt} & =\text { Biomassa ikan pada akhir penelitian }(\mathrm{g}) \\ \mathrm{W}_{\mathrm{O}} & =\text { Biomassa ikan pada awal penelitian }(\mathrm{g}) \\ \mathrm{F} & =\text { Jumlah pakan }(\mathrm{g})\end{array}$

\subsection{Analisis Data}

Analisis data dilakukan untuk mengetahui apakah ada perbedaan antar perlakuan atau tidak, adapun model Rancangan Acak Lengkap (RAL) pola faktorial yang digunakan adalah sebagai berikut (Gaspers, 1991): 


$$
Y i j k=\mu+\alpha i+\beta j+(\alpha \beta) i j+€ i j k
$$

\section{Keterangan :}

Yijk = Nilai pengamatan pada satuan percobaan ke-k yang memperoleh kombinasi perlakuan ijk (taraf ke-i dari faktor A dan taraf ke-j dari faktor B)

$\mu \quad=$ Nilai tengah populasi (rata-rata yang sesungguhnya)

$\alpha \mathrm{i}=$ Pengaruh aditif taraf ke-i dari faktor $\mathrm{A}$

$\mathrm{Bj} \quad=$ Pengaruh aditif taraf ke-j dari faktor $\mathrm{B}$

$(\alpha \beta \mathrm{ij})=$ Pengaruh interaksi taraf ke-i faktor $\mathrm{A}$ dan taraf ke-j faktor B

$€ \mathrm{ijk}=$ Pengaruh galat dari stasiun percobaan ke-k yang memperoleh kombinasi perlakuan ij.

Dari hasil percobaan analisis sidik ragam apabila berdasarkan hasil uji menunjukkan adanya perbedaan nilai yang

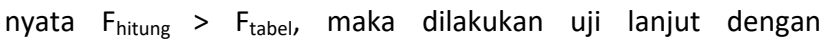
menggunakan uji BNT (Beda Nyata Terkecil).

\section{Hasil dan pembahasan}

\subsection{Kualitas air}

Kualitas air media pemeliharan yang baik dan nyaman dapat meningkatkan pertumbuhan dan kelangsungan hidup bagi ikan yang dibudidayakan. Beberapa parameter kualitas air yang berpengaruh langsung bagi kesehatan dan kehidupan ikan yaitu suhu, Oksigen terlarut (DO), Derajat keasaman (pH), amonia, nitrit, dan nitrat.

\subsubsection{Suhu}

Suhu air mempunyai pengaruh yang besar terhadap metabolisme ikan maskoki. Nilai rata-rata suhu harian media pemeliharaan ikan maskoki dapat dilihat pada Gambar 1.
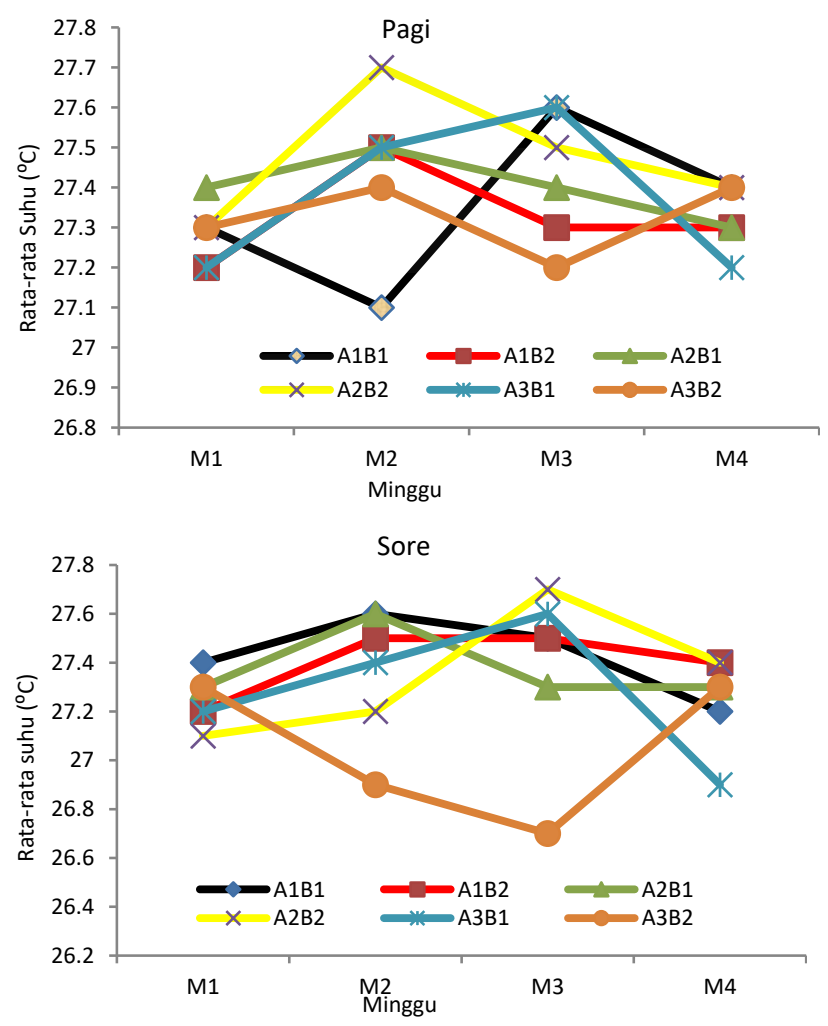

Gambar 1. Rata-rata nilai parameter suhu media.
Parameter suhu selama penelitian pada pagi dan sore hari cenderung stabil dan tetap pada kisaran optimun yang baik untuk pemeliharaan benih maskoki yaitu pada kisaran 27,1-27,7 ${ }^{0} \mathrm{C}$. Hal ini sesuai dengan pendapat Lesmana dan Dermawan (2004) yang menyatakan bahwa ikan maskoki dapat hidup baik pada suhu $19-28{ }^{\circ} \mathrm{C}$ dan suhu optimal $24-28{ }^{\circ} \mathrm{C}$. Jika dibandingkan dengan baku mutu kualitas air pada pp nomor 82 tahun 2001 tentang pengelolaan kualitas air dan pengendalian pencemaran menyatakan bahwa kualitas suhu air normal ikan air tawar yaitu $28-32{ }^{\circ} \mathrm{C}$

\subsubsection{Oksigen terlarut}

Oksigen terlarut sangat diperlukan oleh ikan maskoki dan bakteri yang terdapat dalam probiotik EM4. Nilai rata-rata DO (mg/L) harian selama penelitian dapat dilihat pada Gambar 2.
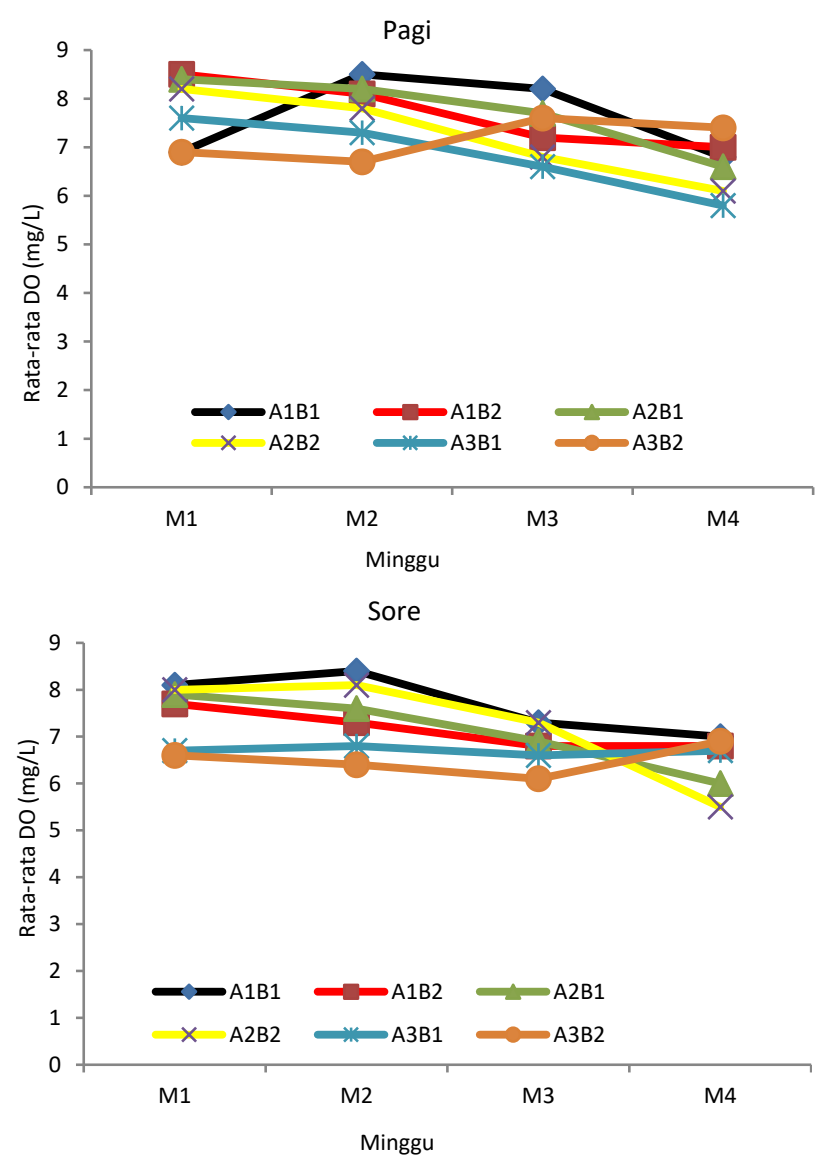

Gambar 2. Rata-rata nilai oksigen terlarut media uji.

Parameter oksigen terlarut (DO) pagi dan sore hari berada pada kisaran nilai yang baik yaitu $6,0-9,0 \mathrm{mg} / \mathrm{L}$, hal in sesuai dengan pendapat Perkasa dan Hisomudin (2003) bahwa maskoki dapat hidup tenang bila kandungan DO minimal $5 \mathrm{mg} / \mathrm{L}$. Baku mutu kualitas air pada pp nomor 82 tahun 2001 tentang pengelolaan kualitas air dan pengendalian pencemaran menambahkan bahwa minimum nilai DO adalah 3-5 mg/L. Dalam kondisi yang cukup oksigen, bahan organik akan diurai secara sempurna oleh bakteri sehingga tidak menghasilkan bahan yang bersifat racun (Suprapto dan Samtamsir, 2013).

\subsubsection{Derajat keasaman $(p H)$}

Derajat keasaman $(\mathrm{pH})$ menunjukkan keadaan air pada kondisi asam atau basa. Nilai rata-rata $\mathrm{pH}$ harian selama penelitian dapat dilihat pada Gambar 3 berikut : 

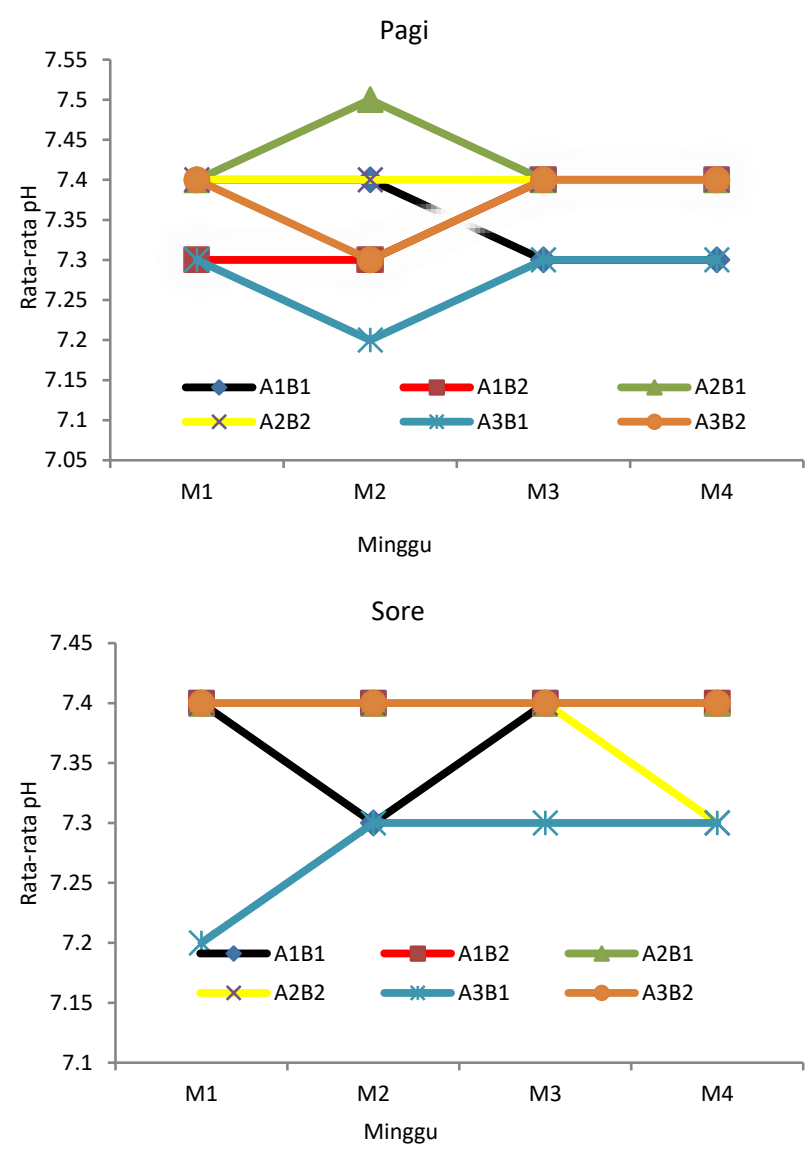

Gambar 3. Rata-rata nilai pH media uji.

Parameter $\mathrm{pH}$ pada media pemeliharaan maskoki berada pada kisaran yang ditentukan yaitu 7,2-7,5, hal ini sesuai dengan pendapat Perkasa dan Hisomudin (2003) yang menyatakan bahwa kisaran ph yang diinginkan maskoki yaitu 7,0-7,5. Baku mutu air pada pp nomor 82 tahun 2001 tentang pengelolaan kualitas air dan pengendalian pencemaran menambahakan bahwa syarat nilai ph yaitu berkisar antara 6-9.

\subsubsection{Amonia}

Amonia merupakan bentuk ekskresi bernitrogen yang bersifat racun bagi ikan. Nilai rata-rata amonia harian selama penelitian dapat dilihat pada Gambar 4.

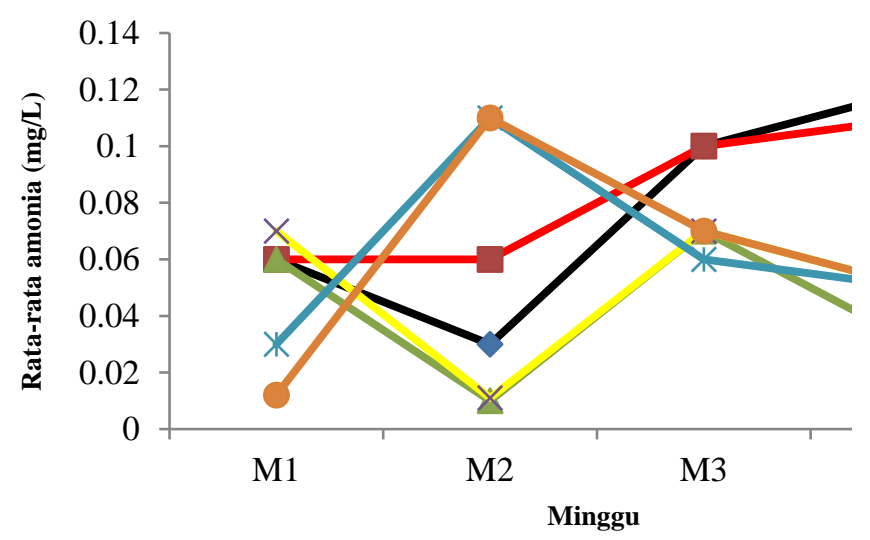

Gambar 4. Rata-rata nilai amonia media uji.

Data parameter amonia menunjukkan kisaran yang baik untuk kehidupan maskoki yaitu dari kisaran 0,03-0,12 mg/L. Hal ini sesuai dengan pendapat Boyd (1990) dalam Beauty et. al.,
(2012) bahwa nilai standar amonia yang diperbolehkan dalam budidaya maskoki yaitu $<0,012 \mathrm{mg} / \mathrm{L}$. Suprapto dan Samtamsir (2012) menambahkan kadar amonia yang dianggap cukup aman adalah di bawah $0,1 \mathrm{mg} / \mathrm{L}$. Jika dibandingkan dengan baku mutu kualitas air pp no. 82 tahun 2001 menyatakan bahwa batas maksimum amonia untuk kegiatan perikanan bagi ikan yang peka $\leq 0,02 \mathrm{mg} / \mathrm{l}$.

Tingginya kadar amonia disebabkan karena penumpukan feses dan sisa pakan pada media pemeliharaan karena tidak adanya pergantian air selama proses penelitian. Olehkarena itu pada perlakuan kontrol menunjukkan nilai amonia yang semakin tinggi dari minggu ke minggu, hal ini dikarenakan tidak adanya bakteri probiotik yang mampu mengurai sisa feses dan sisa pakan. Sedangkan pada perlakuan dengan dosis probiotik menunjukkan kadar amonia yang sesuai dan masih dalan kisaran yang diperbolehkan untuk kehidupan maskoki karena adanya bakteri probiotik yang mampu memanfaatkan kadar amonia didalam media pemeliharaan menjadi sumber energi dan makanannya.

Hal ini sesuai dengan pernyatan Suprapto dan Samtamsir (2013) bahwa amonia akan diubah oleh bakteri menjadi sel protein mikroba, sehingga pada akhir penelitian kandungan nilai amonia semakin menurun. Analisis keragaman amonia selama pemeliharaan benih maskoki menunjukkan hasil yang berpengaruh sangat nyata $\alpha=0.05$ dengan nilai $F_{\text {hitung }}(83,76)>$ $F_{\text {tabel }} 0.05(3,88)$ terhadap nilai amonia selama pemeliharaan benih maskoki yang dihasilkan. Hasil uji BNT amonia menunjukkan bahwa penggunaan probiotik A1B1, A1B2, dan A2B1 berbeda nyata dengan semua perlakuan.

\subsubsection{Nitrit dan nitrat}

Kandungan nitrit dan nitrat selama penelitian juga berada pada kisaran yang baik yang masih bisa ditolerir oleh ikan, hal ini sependapat dengan Perkasa dan Hisomudin (2003) yang menyatakan bahwa normalnya, kandungan nitrit terlarut di dalam air adalah $0,2 \mathrm{mg} / \mathrm{L}$ sedangkan kandungan nitrat yang baik yaitu $40 \mathrm{mg} / \mathrm{L}$. Standar baku mutu air pp no 82 tahun 2001 untuk kegiatan budidaya ikan air tawar, kandungan nitrat yang ditentukan yaitu $10 \mathrm{mg} / \mathrm{L}$. Nilai rata-rata nitrit dan nitrat harian selama penelitian dapat dilihat pada Gambar 5.

Kandungan nitrit dan nitrat untuk perlakuan kontrol selama pemeliharaan benih maskoki tanpa pergantian air semakin meningkat hingga akhir penelitian, yaitu pada kisaran nitrit 0,0061-0,09 $\mathrm{mg} / \mathrm{L}$ dan nitrat 0,0024-3,52 $\mathrm{mg} / \mathrm{L}$. Hal yang berbeda ditunjukkan pada perlakuan dengan penambahan probiotik pada minggu pertama penelitian kandungan nitrit dan nitrat rendah yaitu pada kisaran 0,012-0,016 mg/L, kemudian meningkat pada minggu kedua dan ketiga dari kisaran 0,013$0,027 \mathrm{mg} / \mathrm{L}$ lalu kembali turun pada akhir penelitian (minggu keempat) yaitu dengan kisaran 0,011-0,021 mg/L. Kandungan nitrat yaitu pada minggu pertama penelitian berada pada kisaran 0,023-0,024 mg/L, kemudian meningkat pada minggu kedua dan ketiga dari kisaran $0,026-0,13 \mathrm{mg} / \mathrm{L}$, lalu kembali turun pada minggu keempat yaitu kisaran 0,022-0,026 mg/L. Secara keseluruhan parameter kualitas air selama penelitian dengan pemberian dosis probiotik yang berbeda pada media pemeliharaan berada pada kisaran parameter yang baik untuk pemeliharaan benih maskoki. 

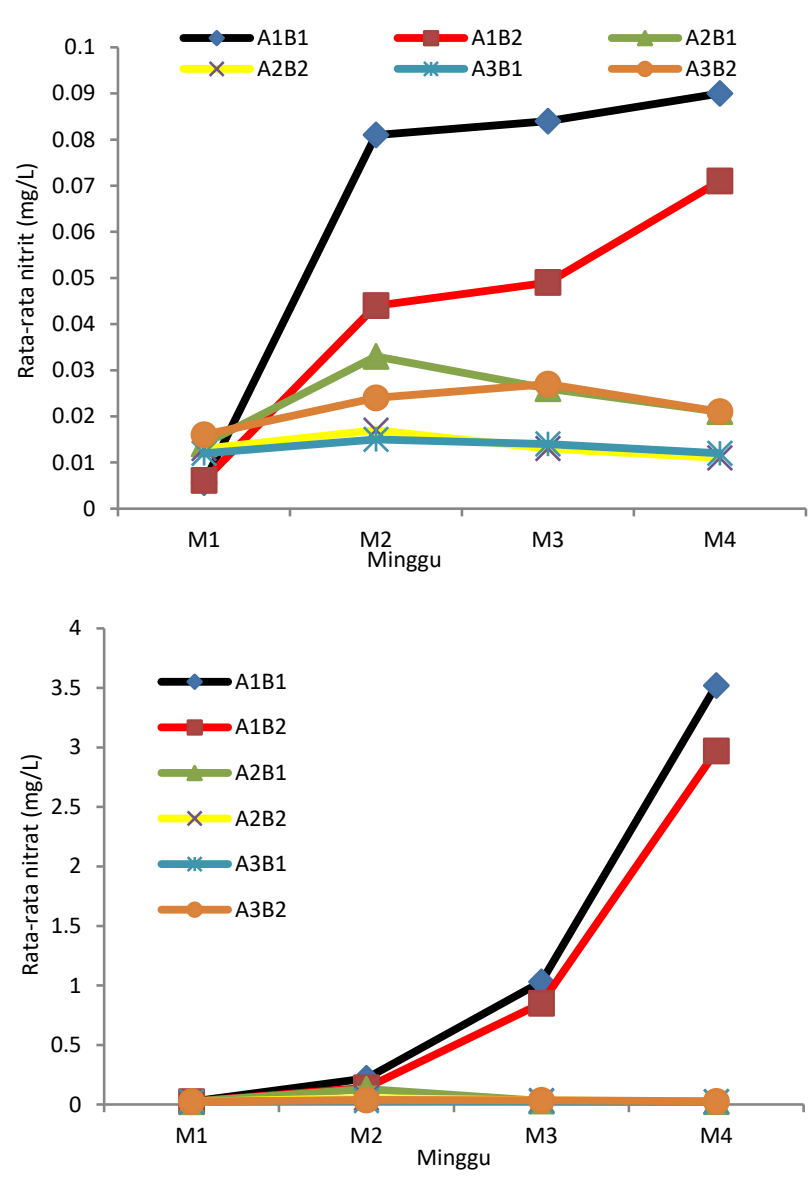

Gambar 5. Rata-rata nilai nitrit dan nitrat media uji.

\subsection{Pertumbuhan}

Pertumbuhan adalah perubahan ukuran panjang dan berat dalam suatu periode waktu tertentu (Putra, 2011). Untuk mengetahui pertumbuhan panjang dan berat ikan maskoki (Carassius auratus) dilakukan pengukuran setiap tujuh hari sekali. Pengamatan pertumbuhan ikan maskoki yang dipelihara selama 28 hari mengalami pertambahan, baik bobot maupun panjang. Berdasarkan hasil penelitian menunjukkan bahwa pemberian dosis probiotik EM4 pada umur benih yang berbeda juga menunjukkan hasil yang berbeda terhadap pertumbuhan berat ikan maskoki. Rata-rata pertumbuhan berat ikan maskoki untuk masing-masing perlakuan dapat dilihat pada Tabel 2.

Tabel 2

Pertumbuhan berat (gr) benih maskoki (Carassius auratus.

\begin{tabular}{ccc}
\hline \multirow{2}{*}{ Dosis perlakuan probiotik } & \multicolumn{2}{c}{ Umur ikan } \\
\cline { 2 - 3 } & B1 (Satu bulan) & B2 (Dua bulan) \\
\hline A1 (kontrol) & 0,25 & 0,27 \\
A2 (1,5 ml/L) & 0,40 & 0,43 \\
A3 (2,0 ml/L) & 0,45 & 0,52 \\
\hline
\end{tabular}

Nilai rata-rata pertumbuhan berat secara berturut-turut, pertumbuhan tertinggi terdapat pada perlakuan $A 3 B 2$ yaitu sebesar 0,52 gr, perlakuan A3B1 sebesar 0,45 gr, perlakuan A2B2 sebesar 0,43, perlakuan A2B1 sebesar 0,40 gr, dan pertumbuhan yang terendah terdapat pada perlakuan A1B2 sebesar 0,27 gr, dan perlakuan A1B1 sebesar 0,25 gr. Untuk lebih jelasnya dapat dilihat pada Gambar 6.

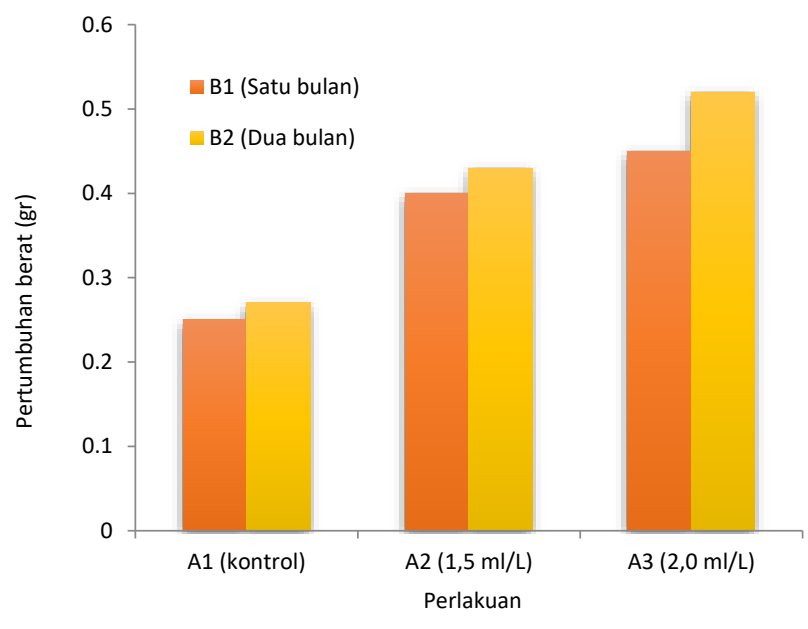

Gambar 6. Pertumbuhan berat (gr) benih maskoki (Carassius auratus).

Berdasarkan hasil penelitian menunjukkan bahwa pemberian dosis probiotik EM4 pada umur benih yang berbeda juga menunjukkan hasil yang berbeda terhadap pertumbuhan panjang ikan maskoki. Rata-rata pertumbuhan panjang ikan maskoki untuk masing-masing perlakuan dapat dilihat pada Tabel 3.

Tabel 3

Pertumbuhan panjang $(\mathrm{cm})$ benih maskoki (Carassius auratus).

\begin{tabular}{ccc}
\hline \multirow{2}{*}{ Dosis perlakuan probiotik } & \multicolumn{2}{c}{ Umur ikan } \\
\cline { 2 - 3 } & B1 (Satu bulan) & B2 (Dua bulan) \\
\hline A1 (kontrol) & 0,20 & 0,25 \\
A2 (1,5 ml/L) & 0,29 & 0,33 \\
A3 (2,0 ml/L) & 0,35 & 0,39 \\
\hline
\end{tabular}

Nilai rata-rata pertumbuhan panjang secara berturutturut, pertumbuhan panjang tertinggi terdapat pada perlakuan A3B2 yaitu sebesar $0,39 \mathrm{~cm}$, perlakuan $A 3 B 1$ sebesar $0,35 \mathrm{~cm}$, perlakuan A2B2 sebesar $0,33 \mathrm{~cm}$, perlakuan A2B1 sebesar 0,29 $\mathrm{cm}$, dan pertumbuhan yang terendah terdapat pada perlakuan A1B2 sebesar 0,25, dan perlakuan A1B1 sebesar 0,20 cm. Untuk lebih jelasnya dapat dilihat pada Gambar 7.

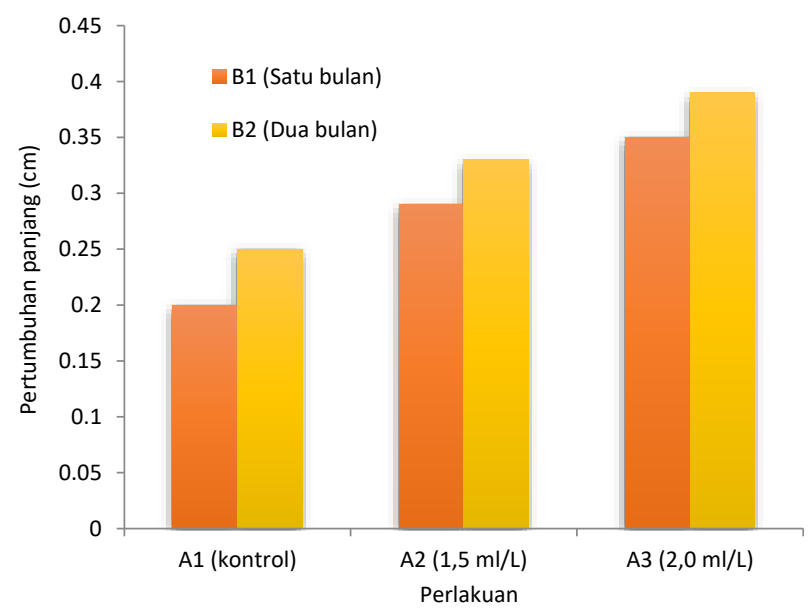

Gambar 7. Pertumbuhan panjang $(\mathrm{cm})$ benih maskoki (Carassius auratus).

Tingkat pertumbuhan berat dan panjang tertinggi pada perlakuan dengan dosis probiotik $2,0 \mathrm{ml} / \mathrm{L}$ masing-masing sebesar 0,52 gram dan 0,39 cm. Pertumbuhan berat dan panjang terendah dihasilkan dari perlakuan tanpa pemberian probiotik masing-masing 0,25 gram dan $0,20 \mathrm{~cm}$. Pertambahan berat dan panjang tubuh ikan maskoki menunjukkan bahwa pemberian 
pakan yang diberi selama pemeliharaan mampu meningkatkan pertumbuhan. Hal ini sesuai dengan pernyataan NRC (1983), pemberian pakan secara optimal mampu memberikan energi yang diperlukan untuk pemeliharaan tubuh dan aktivitas harian ikan sehingga dapat digunakan untuk pertumbuhan.

Penambahan dosis probiotik pada media pemeliharaan menghasilkan pertumbuhan yang lebih tinggi karena adanya bakteri probiotik yang mampu memperbaiki kualitas air media pemeliharaan sehingga kualitas air terjaga dengan baik. Hal ini sesuai dengan pendapat Suprapto dan Samtamsir (2013) yang menyatakan bahwa bakteri probiotik juga mampu mengurai bahan organik dalam air yang berasal dari sisa pakan dan feses ikan serta mampu menghilangkan/memanfaatkan senyawa beracun seperti amonia, nitrit, dan nitrat. Kualitas air media pemeliharaan yang terjaga dengan baik akan memberikan habitat yang nyaman bagi pertumbuhan benih maskoki yang dipelihara (Ditjen Penyuluhan Perikanan, 2007).

Penambahan dosis probiotik pada media pemeliharaan tidak hanya berpengaruh untuk memperbaiki kualitas air, melainkan juga untuk meningkatkan pertumbuhan ikan. Bakteri probiotik secara tidak langsung berinteraksi dengan phytoplankton yang merupakan makanan zooplankton, hal ini menyebabkan perairan tersebut menjadi subur (Hartini et. al., 2013). Zooplankton merupakan pakan alami bagi sebagian besar larva dan benih ikan, termasuk ikan maskoki yang tergolong ikan omnivora.

Rendahnya pertumbuhan pada perlakuan kontrol (A1B1 dan A1B2) disebabkan tidak adanya penambahan probiotik sehingga tidak ada bakteri yang dapat mengoksidasi bahan organik, dengan demikian akan terjadi peningkatan bahan organik pada media pemeliharaan dan akan menjadi racun bagi ikan. Sehingga memicu timbulnya penyakit dan kurangnya nafsu makan dan berakibat pada rendahnya pertumbuhan benih maskoki (Taufik et. al., 2005). Benih ikan yang berumur satu bulan pertumbuhannya lebih rendah disebabkan kekebalan tubuh benih maskoki umur satu bulan lebih rentan dibandingkan dengan maskoki berumur dua bulan.

Analisis keragaman pertumbuhan panjang benih maskoki menunjukkan hasil yang tidak berpengaruh nyata terhadap pertumbuhan panjang yang dihasilkan dari setiap perlakuan. Analisis keragaman pertumbuhan berat benih maskoki menunjukkan hasil yang berpengaruh sangat nyata $(\propto=0.05$

) dengan nilai $F$ hitung $(10,03)>F_{\text {tabel }} 0.05(3,88)$ terhadap pertumbuhan berat benih maskoki yang dihasilkan. Hasil uji BNT pertumbuhan berat menunjukkan bahwa penggunaan probiotik $A 1 B 1$ dan A1B2 berbeda nyata dengan perlakuan A3B1, A3B2, A2B2.

\subsection{Kelangsungan hidup}

Berdasarkan hasil penelitian yang dilakukan selama 28 hari, dapat dilihat tingkat kelangsungan hidup benih maskoki menunjukkan hasil yang berbeda pada masing-masing perlakuan. Rata-rata kelangsungan hidup maskoki dapat dilihat pada Tabel 4.

Tabel 4

Kelangusngan hidup (\%) benih maskoki (Carassius auratus).

\begin{tabular}{ccc}
\hline \multirow{2}{*}{ Dosis perlakuan probiotik } & \multicolumn{2}{c}{ Umur ikan } \\
\cline { 2 - 3 } & B1 (Satu bulan) & B2 (Dua bulan) \\
\hline A1 (kontrol) & 55,00 & 63,33 \\
A2 (1,5 ml/L) & 71,67 & 73,33 \\
A3 (2,0 ml/L) & 66,67 & 68,33 \\
\hline
\end{tabular}

Rata-rata kelangsungan hidup benih maskoki dari setiap perlakuan menunjukkan hasil yang berbeda, untuk lebih jelasnya dapat dilihat pada Gambar 8.

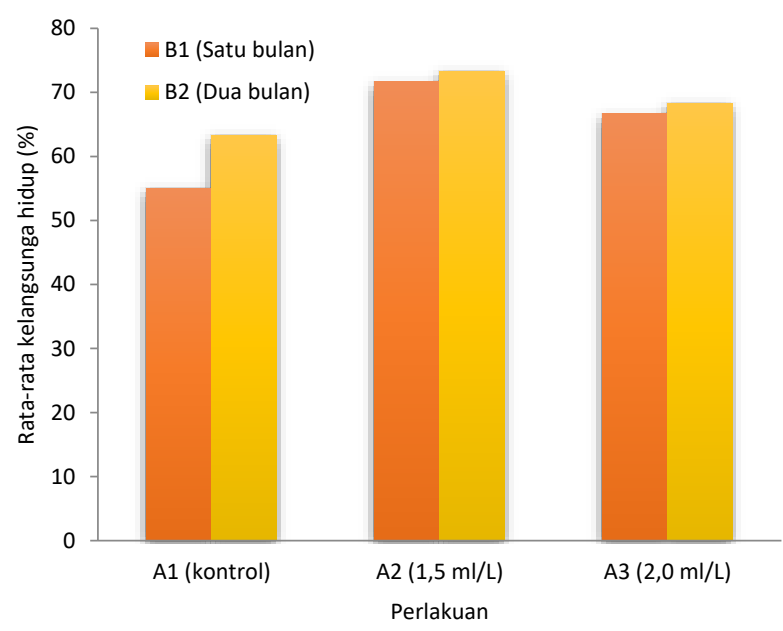

Gambar 8. Kelangsungan hidup benih maskoki (Carassius auratus).

Berdasarkan Tabel 6 dan Gambar 9 diatas dapat dilihat bahwa rata-rata kelangsungan hidup yang tinggi ditunjukkan pada perlakuan dengan dosis probiotik 1,5-2,0 ml/L yaitu sebesar 66,67 - 73,33\%, namun pada perlakuan dosis probiotik $1,5 \mathrm{ml} / \mathrm{L}$ dengan benih maskoki berumur dua bulan menunjukkan tingkat kelangsungan hidup tertinggi dibandingkan dengan perlakuan dosis $2,0 \mathrm{mg} / \mathrm{L}$, hal ini dikarenakan kepadatan bakteri yang tinggi dalam wadah pemeliharaan menyebabkan adanya persaingan dalam pengambilan substrat dan nutrisi antara biomassa bakteri dengan ikan yang dipelihara (Richard, 1993 dalam Putri et. al., 2012).

Tingkat kelangsungan hidup terendah ditunjukkan pada perlakuan kontrol (tanpa pemberian probiotik) yaitu sebesar $55,00-63,33 \%$. Rendahnya tingkat kelangsungan hidup pada perlakuan kontrol (A1B1 dan A1B2) disebabkan kualitas air yang menurun terutama parameter $\mathrm{NH}_{3}$ yang meningkat akibat dari penumpukan feses dan sisa pakan, nilai konsentrasi $\mathrm{NH}_{3}$ pada perlakuan kontrol A1B1 yaitu sebesar $0,12 \mathrm{mg} / \mathrm{L}$ dan $\mathrm{A} 2 \mathrm{~B} 2$ yaitu sebesar $0,11 \mathrm{mg} / \mathrm{L}$. Nilai standar amonia yang diperbolehkan dalam budidaya ikan maskoki yaitu sebesar $<0,012 \mathrm{mg} / \mathrm{L}$ (Boyd, 1990 dalam Beauty et. al., 2012). Suprapto dan Samtamsir (2013) menambahkan kadar amonia yang masih dianggap cukup aman yaitu $0,1 \mathrm{mg} / \mathrm{L}$. Analisis keragaman kelangsungan hidup benih maskoki menunjukkan hasil yang tidak berpengaruh nyata terhadap kelangsungan hidup yang dihasilkan dari setiap perlakuan.

\subsection{Konversi pakan}

Feed Convertion Ratio (FCR)/konversi pakan adalah suatu ukuran yang menyatakan ratio jumlah pakan yang dibutuhkan untuk menghasilkan $1 \mathrm{~kg}$ ikan budidaya (Effendy, 2004). Berdasarkan hasil penelitian menunjukkan bahwa pemberian probiotik EM4 pada umur benih yang berbeda menunjukkan hasil yang berbeda terhadap konversi pakan benih maskoki. Rata-rata konversi pakan benih maskoki (Carassius auratus) selama penelitian untuk masing-masing perlakuan dapat dilihat pada Tabel 5.

Tabel 5

Rata-rata konversi pakan (gr)

\begin{tabular}{ccc}
\hline \multirow{2}{*}{ Dosis perlakuan probiotik } & \multicolumn{2}{c}{ Umur ikan } \\
\cline { 2 - 3 } & B1 (Satu bulan) & B2 (Dua bulan) \\
\hline A1 (kontrol) & 0,81 & 0,54 \\
A2 (1,5 ml/L) & 0,71 & 0,52 \\
A3 (2,0 ml/L) & 0,59 & 0,48 \\
\hline
\end{tabular}


Rata-rata konversi pakan dari setiap perlakuan menjukkan hasil yang berbeda, untuk lebih jelasnya dapat dilihat pada Gambar 9.

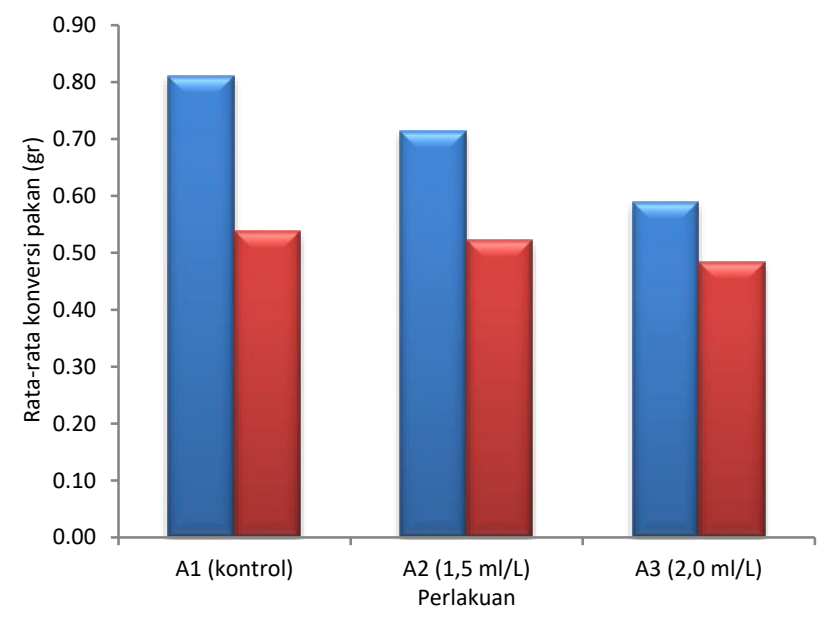

Gambar 9. Rata-rata konversi pakan (gr)

Nilai rata-rata konversi pakan secara berturut-turut. Konversi pakan pada perlakuan A1B1 yaitu sebesar 0,81 gr, perlakuan A1B2 sebesar 0,54 gr, perlakuan A2B1 sebesar 0,71 gr, perlakuan $A 2 B 2$ sebesar 0,52 gr, perlakuan A3B1 sebesar 0,59 gr, dan perlakuan $\mathrm{A} 3 \mathrm{~B} 2$ dengan nilai konversi pakan terbaik yaitu sebesar 0,48 gr. Hasil yang diperoleh dari perhitungan konversi pakan menunjukkan bahwa nilai konversi pakan dari perlakuan dengan dosis probiotik $2,0 \mathrm{mg} / \mathrm{L}$ pada benih maskoki berumur dua bulan (A3B2) sebesar 0,48 gr lebih baik dibandingkan perlakuan lainnya.

Hasil nilai konversi pakan ini didukung oleh penelitian yang dilakukan Sembiring et. al. (2012) dengan hasil konversi pakan terbaik yaitu 0,23 gr. Rendahnya nilai konversi pakan pada perlakuan dengan penambahan probiotik karena adanya bakteri probiotik yang mampu memperbaiki kualitas air media pemeliharaan. Kualitas air yang terjaga dengan baik akan menambah nafsu makan ikan sehingga pakan yang diberikan dapat dimanfaatkan secara efesien oleh ikan. Hal ini sesuai pendapat Schmittows (1992) dalam Qadri (2011) yang menyatakan bahwa beberapa faktor yang menyebabkan besar kecilnya nilai konversi pakan yang dihasilkan dalam pemeliharaan benih maskoki yaitu kualitas dan kuantitas pakan, spesies ikan, ukuran ikan, dan kualitas air media pemeliharaan.

Malik (2008) menambahkan bahwa semakin tinggi pertumbuhan benih maskoki maka semakin rendah konversi pakan yang dihasilkan. Pascual (1984) dalam Qadri (2011) menambahkan bahwa semakin rendah nilai konversi pakan semakin baik karena jumlah pakan yang diberikan untuk meningkatkan pertumbuhan ikan akan semakin sedikit. Analisis keragaman konversi pakan benih maskoki menunjukkan hasil yang tidak berpengaruh nyata terhadap konversi pakan yang dihasilkan dari setiap perlakuan.

\section{Kesimpulan}

Berdasarkan hasil penelitian dapat disimpulkan bahwa:

1. Parameter kualitas air yang diukur selama penelitian menunjukkan kisaran yang sesuai atau masih dapat ditolerir untuk pemeliharaan benih ikan maskoki yaitu pada kisaran suhu $27,1-27,7^{\circ} \mathrm{C}$, DO 6,0-9,0 mg/L, dan pH 7,2-7,5, dengan penambahan probiotik EM4 pada media pemeliharaan tanpa pergantian air selama penelitian terbukti mampu menurunkan amonia dengan kisaran amonia yaitu 0,03-0,12 mg/L, nitrit 0,012-0,090 mg/L, dan nitrat 0,023-3,52 mg/L.

2. Penambahan probiotik EM4 pada media pemeliharaan berpengaruh sangat nyata terhadap pertumbuhan berat tetapi tidak berpengaruh nyata terhadap pertumbuhan panjang dan nilai konversi pakan. Pertumbuhan berat, panjang, dan nilai konversi pakan tertinggi ditunjukkan pada perlakuan dengan dosis $2,0 \mathrm{ml} / \mathrm{L}$ pada benih berumur dua bulan (A3B2) yaitu 0,52 gr, 0,39 cm, dan 0,48 gr.

3. Penambahan probiotik EM4 pada media pemeliharaan tidak berpengaruh nyata terhadap kelangsungan hidup benih maskoki dengan kelangsungan hidup tertingg ditunjukkan pada perlakuan dengan dosis $1,5 \mathrm{ml} / \mathrm{L}$ pada benih berumur dua bulan (A2B2) yaitu sebesar 73,33\%.

\section{Bibliografi}

Afrianto, E. dan Liviawati, E., 1990. Maskoki, Budidaya dan Pemasarannya. Kanisius. Jakarta.

Astutik, S., 2010. Manfaat Dan Aplikasi Probiotik Di Bidang Perikanan.

https://ml.scribd.com/doc/115965180/Manfaat-DanAplikasi-Probiotik-Di Bidang-Perikanan., diakses tanggal 28 Maret 2015.

Beauty, G. Yustiati, A. Grandiosa, R., 2012. Pengaruh Dosis Mikroorganime Probiotik pada Media Pemeliharaan Terhadap kelangsungan Hidup dan Pertumbuhan Benih Maskoki (Carassius auratus) Dengan Padat Tebar Berbeda. Jurnal. Fakultas Perikanan dan Ilmu Kelautan. Universitas Padjadjaran. Bandung.

Ditjen Penyuluhan Perikanan, 2007. Probiotik Untuk Pengembangan Budidaya Ikan.http://mediapenyuluhanperikananpati.blogspot.co m/2014/01/probiotik-untuk-pengembanganbudidaya.html., diakses tanggal 28 Maret 2015.

Effendy, 2004. Konversi Pakan Perikanan. http://fcrranigr.blogspot.com /2012/05/konversi-pakanperikanan.html., diakses tanggal 01 September 2015.

Gaspers, V., 1991. Teknik Analisis Data Dalam Penilitian Percobaan. Tarsito. Bandung.

Hartini, S., A. D. Sasanti., dan H. F. Taqwa, 2013. Kualitas Air, Kelangsungan Hidup Dan Pertumbuhan Benih Ikan Gabus (Channa striata) Yang Dipelihara Dalam Media Dengan Penambahan Probiotik. Jurnal. Universitas Sriwijaya. Indralaya.

Lesmana, D. S dan Dermawan, I., 2004. Budidaya Ikan Hias Air Tawar. Penebar Swadaya. Jakarta.

Malik, A., 2008. Pengaruh Pemberian Suplemen dan Probiotik Terhadap Hasil Panen Bandeng (Chanos chanos) di Wilayah Desa Kentong Kecamatan Glagah Kabupaten Lamongan. Jurnal. Universitas Islam Lamongan.

Murtidjo, B. A., 2001. Pedoman Meramu Pakan Ikan. Kanisius. Yogyakarta. 
National Research Cauncil (NRC), 1983. Nutrient Requirement of Warm Fishes and Sellfishes. National Academy Press. Washington DC.

Parasmewari, W., Sasanti. A. D., dan Muslim, 2013. Populasi Bakteri, Histologi, Kelangsungan Hidup Dan Pertumbuhan Benih Ikan Gabus (Channa striata) Yang Dipelihara Dalam Media Dengan Penambahan Probiotik. Jurnal. Program Studi Budidaya Perairan Fakultas Pertanian. Universitas Sriwijaya. Indralaya.

Perkasa, B. E. dan Hisomudin, 2003. Permasalahan Maskoki dan Solusinya. Penebar Swadaya. Jakarta.

Putra, A.A.S., 2011. Kamus Istilah Perikanan. Yayasan PeNA. Banda Aceh.

Putri. F. S. Hasan, R. dan Haetami, K., 2012. Pengaruh Pemberian Probiotik Pada Pelet Yang Mengandung Kaliandra (Calliandracalothyrsus) Terhadap Pertumbuhan Benih Ikan Nila (Oreocrhomis niloticus). Jurnal. Fakultas Perikanan Dan Ilmu Kelautan. Universitas Padjajaran. Bandung.

Qadri, M. S. 2011. Respon Biologis Pakan Buatan yang Menggunakan Beberapa Sumber Tepung Rumput Laut (Eucheuma spp) pada Ikan Nila Gift. Jurnal. Universitas Hisanuddin. Makassar.

Schryver, P. D. Crab, R. Defoirdt, T. Boon, N dan Verstraete, W., 2008. The Basics of Bio-flocs Technology: The Added Value for Aquaculture. Aquaculture 277: 125-137.

Sembiring, D. R. N., Eriyusni., dan Lesmana. I., 2012. Pengaruh Pemberian Hormon Tiroksin Pada Pakan Terhadap Pertumbuhan Ikan Maskoki (Carrasius auratus). Jurnal. Program Studi Manajemen Sumberdaya Perairan Fakultas Pertanian. Universitas Sumatera Utara. Medan.

Suprapto, N. S dan Samtamsir, L. S., 2013. Rahasia Sukses Teknologi Budidaya Lele Hemat Lahan, Hemat Air, Hemat Pakan, Lebih Bersih, dan Non-residu Serta Kualitas Daging Lebih Enak. Agromedia 165. Depok-Jawa Barat.

Taufik, I., H. Supriadi, I. Muthalib, P. Yulianti, dan S. Subandiyah, 2005. Studi Pengaruh Suhu Air Terhadap Aktifitas Bakteri Bioremediasi pada Pemeliharaan Benih Ikan Patin Siam (Pangasius hypopthalmus). Jurnal Penelitian Perikanan Indonesia. 